\title{
CD177 Antigen
}

National Cancer Institute

\section{Source}

National Cancer Institute. CD177 Antigen. NCI Thesaurus. Code C113575.

CD177 antigen (437 aa, $46 \mathrm{kDa}$ ) is encoded by the human CD177 gene. This protein is involved in coagulation. 